introduction to the 1961 edition of the Zakon Sudnyi liudem, and miscellaneous reviews of books and journals devoted to south Slavia. These reviews from the mid-1940s are marred by a tendentious neo-Pan-Slav tenor (as are several of the articles), and do little to serve the memory of an important Soviet historian. The reader cannot help wondering if Tikhomirov's memory might not have been better served by submitting the previously unpublished materials included here to the appropriate specialized journals, and devoting the paper used for this padded volume to publishing Tikhomirov's "largely completed" book on the early Russian chronicles (see the introduction, p. 12), of which the previously mentioned article on a Russian source of Dlugosz's chronicle is a chapter.

George P. Majeska

State University of New York, Buffalo

\title{
VNESHNIAIA POLITIKA DREVNEI RUSI. By V. T. Pashuto. Moscow: "Nauka," 1968. 472 pp. 1.80 rubles.
}

The foreign relations of Kievan Russia were far more active than many Western scholars have recognized. This study traces their growth and diversity and describes some of the problems that Early Rus' encountered in establishing relations abroad. The author, a well-known specialist in the "period of feudalism," has divided his work into two parts: the first covering the early tenth to the end of the eleventh century, and the second dealing with the end of the eleventh century to the Mongol conquest. The organization is topical and chronological. Although the larger view of foreign relations is sometimes obscured by the magnitude of the subject and by frequent transitions in discussion from one region of Europe and Asia to another, this is not a serious handicap in a work that is well written and packed with illuminating information. Indeed, one can feel only admiration for the author's prodigious exploration of Russia's neglected involvement in many affairs of Europe and Asia that affected trade, territorial expansion, war, and dynastic interest.

Pashuto is obviously sympathetic with the efforts of Rus' to expand and to overcome foreign opposition to the spread of Russian influence over neighboring peoples. Powerful foreign princes, he emphasizes, were generally hostile to Rus' and sought to discourage its growth. The foreign policy of Rus' he sees as an extension of the internal policies of the ruling class that were realized through diplomacy, war, and various forms of political and economic pressure. Russia in the first period of its foreign relations was an emerging polity that had ill-defined borders and tenuous connections with many neighboring peoples whose political organization was primitive. Foreign relations were implemented by campaigns into neighboring and distant lands in search of trade and trade agreements. The acceptance of Christianity by Rus' strengthened and determined its foreign relations and brought it "into the circle of great Christian powers of the medieval world" without subordinating its diplomacy to the church. Pashuto emphatically rejects the concept of a Scandinavian conquest of Rus', and suggests that although Russia and England both came simultaneously into the orbit of Scandinavian conquests, Rus' knew how to protect its independence while England did not. In the second stage of foreign relations, the influences of polycentrism prevailed. Strong princes and towns acted independently, established relations with outside powers, and precipitated internecine struggles that undermined the nascent "unity" in foreign policy. Tradition, nevertheless, continued to be influential even in this period and promoted alliances that were 
generally hostile to the expansionist tendencies of the German and Byzantine empires and to papal universalism. In the thirteenth century the foreign relations of Rus' changed. Although the early century was generally peaceful, alien peoples soon penetrated different parts of Kievan Russia until the second quarter of the century when their inroads became serious assaults. While Suzdal-Novgorod won victories over the troops of Sweden, the German Order, and Denmark, the southern principalities suffered Mongol attacks that changed their political nature and ushered in a new period of foreign relations.

Though Pashuto does little more than outline Russian foreign interests in many parts of his study, he does supply a surprising amount of fascinating detail that should alter traditional views of Kievan Russia's modest role in European history. It is this information and the substantial footnotes and bibliography (over one hundred pages) that are the most important contributions of the book.

Many readers will not subscribe to some of the author's socioeconomic premises, to the large place he assigns Russia in medieval Europe, or to the contrasts he finds in the nature of Russian vis-à-vis West European territorial expansion. Despite these differences, the work should be welcomed for the many new views it presents of medieval foreign relations over a period of three and a half centuries.

\section{BICKFORd O'BRIEN \\ University of California, Davis}

FORSCHUNGEN ZUR OSTEUROPÄISCHEN GESCHICHTE, vol. 14. Osteuropa-Institut an der Freien Universität Berlin, Historische Veröffentlichungen. Berlin and Wiesbaden: Otto Harrassowitz, 1969. 237 pp. DM 48, paper.

This volume contains two unrelated works. The first, by Frank Kämpfer, is on the sources for the Kazan campaign of Ivan the Terrible. The author agrees with Edward Keenan that they are still too little analyzed; but unlike Keenan he does not turn to a systematic criticism and a study of their authenticity (see p. 78). Instead he confines himself to raising questions while centering his attention on the "meaning" of the sources (p. 79). For this purpose he compares the different existing records (aware that they are those of the victor) and examines in particular the catuses they adduce for the attack on Kazan-to spread the faith, recover the tsar's votchina, gain security for Muscovy, punish perfidious neighbors, and free enslaved Christian prisoners. Of course, greed is also involved. Kämpfer stresses (perhaps overstresses) the religious motives, pretensions, and connotations (which he feels Keenan has considered insufficiently) and the parallels which in this respect exist between the accounts of the Kazan campaign and those of Dmitrii Donskoi in 1380. As is to be expected, the author can again and again demonstrate that the Kazan sources follow precedents set in earlier times.

Minute research characterizes this work, which, though not exciting, is useful for an understanding of many details and for the comparisons it makes. Some statements seem doubtful, such as the one that the founding of Sviazhsk was "without historical parallel" (how about the founding of Ivangorod earlier?), but references to legends embodied in the sources, to views of men like Maxim the Greek and Peresvetov about good government, to personal traits of Ivan, and so forth, add to the usefulness of the work.

The second monograph, by Jack M. Culpepper, reviews, on the basis of 